\title{
КОЛОЇДНО-ХІМІЧНІ АСПЕКТИ ВІДМОЧУВАЛЬНО-ЗОЛЬНИХ ПРОЦЕСІВ ВИГОТОВЛЕННЯ ЕЛАСТИЧНИХ ШКІР
}

\author{
А.Г. Данилкович ${ }^{1}$, О.В. Сангінова ${ }^{2}$, В.І. Ліщук ${ }^{1}$ \\ ${ }^{1}$ Київський національний університет технологій та дизайну \\ вул. Немировича-Данченка, 2, Київ, 01011, Україна \\ ${ }^{2}$ Національний технічний університет Украӥни \\ «Київький політехнічний інститут ім. Ігоря Сікорського» \\ пр. Перемоги, 37, Київ, 03056, Україна \\ e-mail: sanginova@xtf.kpi.ua
}

Виробництво натуральних шкіряних матеріалів характеризується багатостадійністю, тривалістю, використанням значних об'ємів хімічних реагентів різного хімічного складу і структури, в тому числі екологічно небезпечних, особливо на стадії відмочування-зоління шкіряної сировини [1]. У зв'язку з цим виникає об'єктивна необхідність у розробленні інноваційних та удосконаленні існуючих технологій, ефективного використання хімічних реагентів, у тому числі й води, реконструкції очисних споруд [2], а також проведенні моніторингу на всіх стадіях технологічного циклу виробництва шкіряних матеріалів.

Метою роботи є порівняльний екологічний аналіз процесів відмочування-зоління шкіряної сировини у технологіях виробництва еластичних шкір.

Розроблена маловідхідна технологія відмочування-зоління виконується за стабільної температури $27-29{ }^{\circ} \mathrm{C}$ при співвідношенні технологічного розчину / напівфабрикат - рідинний коефіцієнт (РК) з додаванням 0,5 \% карбонату натрію від маси мокросоленої сировини. Процес завершується подвійним промиванням відмоченої сировини. Відмочування сировини проводиться у барабані Вулкан об'ємом 21,0 м³ фірми Olcina (Іспанія) при швидкості обертання 3-4 хв ${ }^{-1}$ протягом 50 \% загального часу з періодичністю 0,5 год обертання і спокою.

Для зоління сировини використовується, \% від маси сировини: гідросульфід натрію - 0,6, сульфід натрію - 0,6, гідроксид кальцію - 1,0. Відпрацьований технологічний розчин має $\mathrm{pH}$

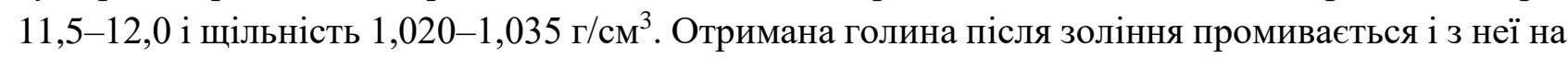
міздрильній машині видаляється підшкірна клітковина. Потім отриманий напівфабрикат розділяється на двоїльно-стрічковій машині на два шари на необхідну товщину лицьового шару. Подальші процеси і операції виготовлення шкіри виконуються за діючою технологією.

Колоїдно-хімічні властивості відпрацьованих відмочувально-зольних суспензій після оброблення шкіряної сировини наведені в табл. 1. Отримані дані свідчать про суттєво більший вміст у відпрацьованих розчинах неорганічних речовин. 


\section{Фізико-хімічні властивості відпрацьованих технологічних суспензій оброблення шкіряної сировини}

\begin{tabular}{|c|c|c|c|c|}
\hline \multirow[b]{2}{*}{ Показник } & \multirow{2}{*}{$\begin{array}{c}\text { Разом } \\
\text { на } 1 \text { т } \\
\text { сировини }\end{array}$} & \multicolumn{3}{|c|}{ Технологічний процес } \\
\hline & & відмочування & зоління & $\begin{array}{c}\text { знезолювання- } \\
\text {-м'якшення }\end{array}$ \\
\hline БСК-5, кг & $57,0 / 74,0$ & $7,0 / 9,0$ & $49,5 / 62,5$ & $1,5 / 2,5$ \\
\hline ХСК, кг & $139,0 / 168,0$ & $30,0 / 33,0$ & $105,0 / 119,0$ & $4,0 / 6,0$ \\
\hline Окиснюваність, кг & 77,0 / 98,0 & $12,0 / 17,0$ & $65,0 / 81,0$ & - \\
\hline Завислі речовини, кг & $82,0 / 96,0$ & $7,0 / 8,0$ & $72,0 / 83,0$ & $3,0 / 5,0$ \\
\hline Хлориди, кг & $172,0 / 179,0$ & $150,0 / 150,0$ & - & $22,0 / 29,0$ \\
\hline
\end{tabular}

Примітка. Чисельник і знаменник відповідають показникам маловідходної і діючої технологій

Діюча технологія відмочувально-зольних процесів оброблення шкіряної сировини виконувалась 3 використанням того ж технологічного обладнання і режиму його обертання, але за нижчої температури $-20-22{ }^{\circ} \mathrm{C}$, промиванням сировини перед відмочуванням зі зміною води через 0,5 год і додаванням $0,3 \%$ карбонату натрію від маси сировини у другу промивну воду при РК 1,5. Відмочування виконується при РК 1,5 з додаванням 1,6 \% карбонату натрію. Для зоління витрачається, \% від маси сировини: сульфід натрію у два прийоми по 1,5 3 інтервалом 1 год, гідроксид кальцію - 4,2 [3]. Отримані дані свідчать також про значно більший вміст мінеральних речовин у відпрацьованих розчинах (табл. 1).

Отримані результати проведеного дослідження свідчать про те, що маловідхідна технологія відмочування-зоління шкіряної сировини характеризується зменшеною витратою сульфідів у 2,4 рази, гідроксиду кальцію у 8 раз при менших затратах електричної енергії у 1,7 рази та скороченні загальної тривалості оброблення у 2,3 рази. При цьому зменшуються загальні витрати хімічних реагентів у 2,2 рази і води на 2,9 $\mathrm{m}^{3} / \mathrm{T}$ сировини. Водночас відпрацьовані розчини маловідходної технології мають менший вміст сульфідів і гідроксиду кальцію відповідно у 2,9 і 4,2 рази порівняно з діючою технологією. Про це свідчать витрати кисню для знешкодження екологічно небезпечних невикористаних хімічних реагентів.

Отже, за комплексом еколого-технологічних показників маловідходна технологія відмочувально-зольних процесів має суттєві переваги перед діючою технологією при виготовленні еластичних шкір для верху взуття. 
Особливості досліджуваних технологій відмочувально-зольних процесів шкіряної сировини

\begin{tabular}{|l|c|c|}
\hline \multicolumn{1}{|c|}{ Показник } & \multicolumn{2}{c|}{ Технологія } \\
\cline { 2 - 3 } & маловідходна & діюча \\
\hline Матеріаловитрати, кг/т & 58,5 & 129,3 \\
Витрата води, ${ }^{3} / \mathrm{T}$ & 8,6 & 11,5 \\
Тривалість загальна, год & 19,0 & 44,5 \\
Вміст у відпрацьованій рідині, г/дм ${ }^{3}:$ & & \\
$\mathrm{Na}_{2} \mathrm{~S}$ & 2,75 & 8,0 \\
$\mathrm{Ca}(\mathrm{OH})_{2}$ & 3,6 & 16,0 \\
Споживання електричної енергії, кВт/т & 22,7 & 38,3 \\
\hline
\end{tabular}

Таблиця 3.

Фізико-хімічні властивості напівфабрикату і шкіри для верху взуття

\begin{tabular}{|l|c|c|}
\hline \multicolumn{1}{|c|}{ Показник } & \multicolumn{2}{c|}{ Технологія } \\
\cline { 2 - 3 } & маловідходна & діюча \\
\hline Набухання голини, \% & 21,0 & 26,0 \\
Витоплення желатину, \% сухого залишку & 9,0 & 12,0 \\
Ферментно-термічна стійкість, хв & 55,0 & 52,0 \\
Пористість, \%, сировини & 44,0 & 44,0 \\
- голини & 52,0 & 50,0 \\
- шкіри & 54,0 & 53,0 \\
Гідротермічна стійкість, ${ }^{\circ}$ С, сировини & 65,0 & 65,0 \\
- необеззоленої голини & 56,0 & 54,0 \\
Границя міцності, МПа & 23,0 & 21,5 \\
Шкіри з пухлинуватими пашинами і пухлинуватістю, \% & - & 18 \\
Вихід площі шкіри, \% & 92,5 & 89,0 \\
\hline
\end{tabular}

Результати визначення технологічних i фізико-хімічних властивостей отриманих еластичних шкір для верху взуття наведені в табл. 3 свідчать про те, що за комплексом структурно-чутливих показників золений напівфабрикат, отриманий за маловідходною технологією, характеризується дещо вищою стабільністю структури порівняно з діючою технологією. Про це свідчать менші величини набухання і витоплення желатину, більша стійкість до дії ферментів у першому випадку. Адекватно цьому отримані еластичні шкіри 
характеризуються вищою міцністю, відсутністю дефекту пухлинуватих пашин i пухлинуватості. Помірне набухання золеного напівфабрикату забезпечує формування готової шкіри з більшим виходом площі на 3,9 \% i, відповідно, більш ефективним використанням шкіряної сировини.

Отже, маловідходна технологія відмочування-зоління виготовлення еластичних шкір для верху взуття може розглядатись більш екологічно безпечною як за меншим вмістом екологічно небезпечних реагентів у відпрацьованих розчинах, так і за скороченням тривалості оброблення сировини. При цьому забезпечується формування якісних еластичних шкір для верху взуття.

Висновки. Досліджено колоїдно-хімічні особливості відмочувально-зольних процесів оброблення шкіряної сировини при виготовленні еластичних шкір для верху взуття. Результатами дослідження ступеня окиснення екстрагованих органічних неструктурованих компонентів дерми в робочих розчинах і набухання прозоленого напівфабрикату встановлено більш глибокі структурні зміни голини отриманої за діючою технологією, що обумовлено більшими витратами гідроксиду кальцію i тривалістю оброблення напівфабрикату. Встановлено, що маловідхідна технологія відмочування-зоління за комплексом фізикохімічних властивостей напівфабрикату характеризується меншими витратами екологічно небезпечних реагентів порівняно з діючою технологією, а саме сульфідів натрію і гідроксиду кальцію відповідно в 2,9 і 4,2 рази та скороченням загальної тривалості оброблення у 2,3 рази. Отриманий золений напівфабрикат за комплексом структурно-чутливих показників характеризується вищою стабільністю структури. Розроблена екологічно орієнтована маловідхідна технологія забезпечує отримання шкір для верху взуття з підвищеним виходом площі на 3,9 \%, які відповідають вимогам ДСТУ 3115-95.

\section{Література:}

1. Katie H. Sizeland, Richard L. Edmonds, Melissa M. Basil-Jones, Nigel Kirby, Adrian Hawley, Stephen Mudie, and Richard G. Haverkamp. Changes to Collagen Structure during Leather Processing. J. Agric. Food Chem. 2015, 63. P. 2499-2505.

2. Саблій Л. А. Фізико-хімічне та біологічне очищення висококонцентрованих стічних вод: монографія. Рівне : НУВГП, 2013. 291 с.3

3. Технологічна методика виробництва шкір різноманітного асортименту для верху взуття і підкладки взуття, галантерейних виробів із шкур великої рогатої худоби та кінських. Київ : АТ Чинбар, 2003. 64 с. 